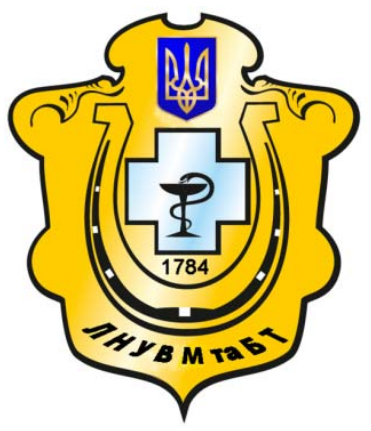

Науковий вісник Львівського національного університету ветеринарної медицини та біотехнологій імені С.З. Гжицького

Scientific Messenger of Lviv National University of Veterinary Medicine and Biotechnologies named after S.Z. Gzhytskyj

doi:10.15421/nvlvet6648

ISSN 2413-5550 print

ISSN 2518-1327 online

$\underline{\text { http://nvlvet.com.ua/ }}$

\title{
Znaczenie badania USG w chorobach kolkowych koni
}

\author{
A. Pomorska-Zniszczyńska, B. Kaczmarek, K. Lutnicki \\ Zakład Chorób Wewnętrznych Zwierząt Gospodarskich i Koni \\ Wydział Medycyny Weterynaryjnej UP w Lublinie
}

\begin{abstract}
Choroby morzyskowe koni maja niejednokrotnie dramatyczny przebieg, a towarzyszace im emocje, zarówno ze strony opiekuna jak i niekiedy lekarza weterynarii dodatkowo moga utrudniać przeprowadzenie prawidlowego rozpoznania. Diagnostyka jest o wiele trudniejsza w porównaniu do innych przypadków chorobowych, ze względu na presję czasu i duży obszar jam ciała, w których toczy sie proces chorobowy. Stad poszukiwania dodatkowych metod instrumentalnych wspomagajacych rozpoznanie sa jak najbardziej uzasadnione. W przypadku dorostych koni badanie radiologiczne jamy brzusznej ma niewielka przydatność diagnostyczna, natomiast coraz szerzej wykorzystywane jest badanie ultrasonograficzne (USG) wykonywane przez powtoki brzuszne. Celem pracy byto porównanie przydatności i skuteczności badania klinicznego oraz badania USG (analizowanych razem i osobno) w rozpoznawaniu chorób kolkowych koni. Z praktycznego punktu widzenia, $w$ kontekście poszukiwania prostych $i$ szybkich schematów diagnostycznych, jest to uzasadnione. Badania dotyczyły koni różnych ras i ptci, z objawami kolki, u których wtaściciele nie wyrazili zgody na leczenie operacyjne. Konie zostały poddane standardowej procedurze diagnostycznej (badanie kliniczne wraz z sondowaniem żołądka oraz badaniem przez prostnice). Następnie dodatkowo wykonywano USG jamy brzusznej i miednicznej wedtug protokolu FLASH, polegajace na badaniu za pomoca sondy 2,5-3,5 MHz kolejno w poszczególnych oknach: po stronie lewej - dót jamy brzusznej, okolica żoładkowa, nerkowo-śledzionowa, lewa słabizna. Po stronie prawej: dwunastnica, prawa słabizna, okolica piersiowa. Rozpoznania byty konfrontowane z wynikami badania sekcyjnego. Rozpoznanie na podstawie badania klinicznego byto zgodne w 87,5\% przypadków z wynikiem badania sekcyjnego. Natomiast badanie USG w 50\%. Badanie USG polegało głównie na ocenie stanu błony śluzowej żoładka, zbadaniu odcinka dwunastnicy wychodzacej bezpośrednio z żoładka, perystaltyki jelit cienkich, ich wypetnienia oraz ułożenia. Umożliwia ono wizualizację wgłobienia jelit i zwiększonej objętości wolnego płynu w jamie brzusznej. Zwiększona ilość wolnego płynu w jamie brzusznej ułatwia wizualizację poszczególnych narządów i ocenę narząów miąższowych, co ma niebagatelnq wartość rokownicza. Badanie USG nie w każdym przypadku przynosi oczekiwany efekt. We wczesnym stadium szybko rozwijającego się procesu nie dochodzi jeszcze do gromadzenia się gazu czy ptynu w jelitach. Często przemieszczenia jelit sa poza zasięgiem sondy, jak przy przemieszczeniu okrężnicy dużej w kierunku przepony oraz uwięźnięciu jelit w otworze sieciowym możemy wówczas obserwować tylko pośrednie objawy. Prawidtowo wykonane badanie kliniczne daje petny obraz stanu układu pokarmowego, pozwala ocenić perystaltyke, położenie oraz stopień wypetnienia jelit. Badanie USG jest trudniejsze i dostarcza nam podobnych informacji, jednakże powinno być uzupetnieniem badania klinicznego.
\end{abstract}

Stowa klucze: kolka, koń, usg, ostry brzuch, badanie kliniczne

Citation:

Pomorska-Zniszczyńska, A., Kaczmarek, B., Lutnicki, K. (2016). Ultrasound examination in horse with colic. Scientific Messenger LNUVMBT named after S.Z. Gzhytskyj, 18, 2(66), 231-233.

\section{Wstęp}

Jednym z poważniejszych stanów chorobowych u koni są kolki. Mają one nie jednokrotnie dramatyczny przebieg a towarzyszące im emocje zarówno ze strony właściciela jak i lekarza weterynarii nie ułatwiają prawidłowego rozpoznania. Trudności w rozpoznaniu jednostki chorobowej wynikają przede wszystkim z wielkości jamy brzusznej. W badaniu klinicznym mamy tylko częściowy dostęp do struktur tam zawartych, czy to przez osłuchiwanie czy badanie per rectum. Badana dodatkowe takie jak RTG u dorosłych koni ma bardzo ograniczoną rolę i jest przydatne tylko w nielicznych przypadkach zapiaszczenia lub kamieni jelitowych. Coraz częściej jako badanie dodatkowe wykorzystywane jest USG. Badanie to jest nieinwazyjne, więc na ogół bardzo dobrze znoszone przez pacjentów. Pozwala ono na szybkie ustalenie czy koń może być leczony zachowawczo czy wymaga natychmiastowej interwencji chirurgicznej. Najczęściej wykorzystywaną metodą w naszej klinice jest protokół FAST- Fast localised abdomen sonography of horse. Badanie pozwala na uwidocznienie około $20 \mathrm{~cm} \mathrm{w}$ głąb jamy brzusznej. Metoda ta polega zobrazowaniu jamy brzusznej w tzw. siedmiu oknach. Cztery $\mathrm{z}$ nich znajdują się po stronie lewej, trzy po stronie prawej (Tab.1.).

FAST jest to skrócone badanie ultrasonograficzne jamy brzusznej. Zajmuje ono około 15 minut i wymaga 
tylko podstawowego przeszkolenia z zakresu ultrasonografii, a więc może być doskonałym narzędziem dla mało doświadczonego lekarza weterynarii.

Badanie rozpoczynamy po stronie lewej od zobrazowania żołądka. Jego okno znajduje się w drugiej poziomej linii opukowej, w dziesiątej przestrzeni międzyżebrowej. Następnie głowicę przesuwamy dwie przestrzenie międzyżebrowe do czaszkowo i dwie przestrzenie do ogonowo. Kolejno przechodzimy do okna nerkowo-śledzionowego, znajdującego się w pierwszej poziomej linii opukowej, w siedemnastej przestrzeni międzyżebrowej. Tu zwracamy szczególną uwagę na ewentualną obecność okrężnicy dużej, przemieszczonej na więzadło nerkowo-śledzionowe. Kolejnym oknem jest okno brzucha, znajdujące się w linii białej ciągnące się od mostka aż do pępka. W linii tej możemy zobrazować ruch jelit cienkich a w sytuacjach patologicznych najszybciej zauważymy tu zbierający się płyn. Ostatnim oknem po tej stronie jest okno lewej słabizny, w którym fizjologicznie obrazujemy pokłady okrężnicy. Po stronie prawej oknem, od którego rozpoczynamy badanie jest okno dwunastnicy. Znajduje się ono w drugiej poziomej linii opukowej między czternastą a piętnastą przestrzenią międzyżebrową. Możemy tam znaleźć poziomą część dwunastnicy, odchodzącą od żołądka. Drugim oknem jest okno prawej słabizny, w którym do badania dostępne jest jelito ślepe. Trzecim oknem po prawej stronie jest okno czaszkowo-brzuszno-piersiowe, znajdujące się w trzeciej poziomej linii opukowej w przestrzeniach międzyżebrowych, tuż za mięśniem trójgłowym ramienia. W tym oknie możemy zaobserwować tylko zmiany patologiczne np. prawostronne przemieszczenie okrężnicy dużej.

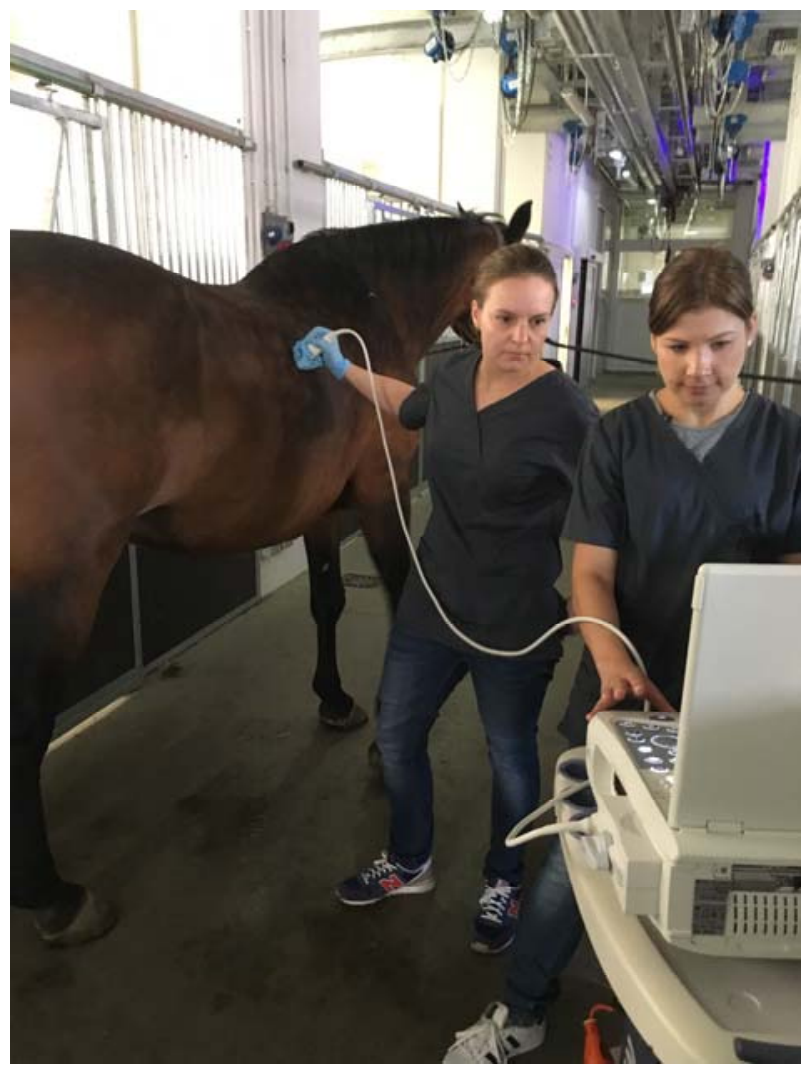

\begin{tabular}{|l|l|l|}
\hline Lewa strona: & Lokalizacja & Obraz \\
\hline Okno żołądka & $\begin{array}{l}2 \text { pozioma linia opukowa } 10 \text { p.m.ż. } \\
2 \text { przestrzenie do czaszkowo i } \\
2 \text { przestrzenie doogonowo }\end{array}$ & żołądek \\
\hline Okno nerkowo-śledzionowe & 1 pozioma linia opukowa 17 p.m.ż. & Więzadło nerkowo-śledzionowe \\
\hline Okno lewej słabizny & lewa słabizna & Pokłady okrężnicy \\
\hline Okno brzucha & w linii białej od mostka do pępka & Ruch jelit cienkich \\
\hline Prawa strona: & 2 pozioma linia opukowa 14-15 p.m.ż. & Wyjście dwunastnicy z żołądka \\
\hline Okno dwunastnicy & Prawa słabizna & jelito ślepe \\
\hline Okno prawej słabizny & $\begin{array}{l}\text { Tuż za mięśniem trójgłowym ramienia } \\
\text { w 3 poziomej linii opukowej }\end{array}$ & \\
\hline Okno czaszkowo-brzuszno-piersiowe & \\
\hline
\end{tabular}
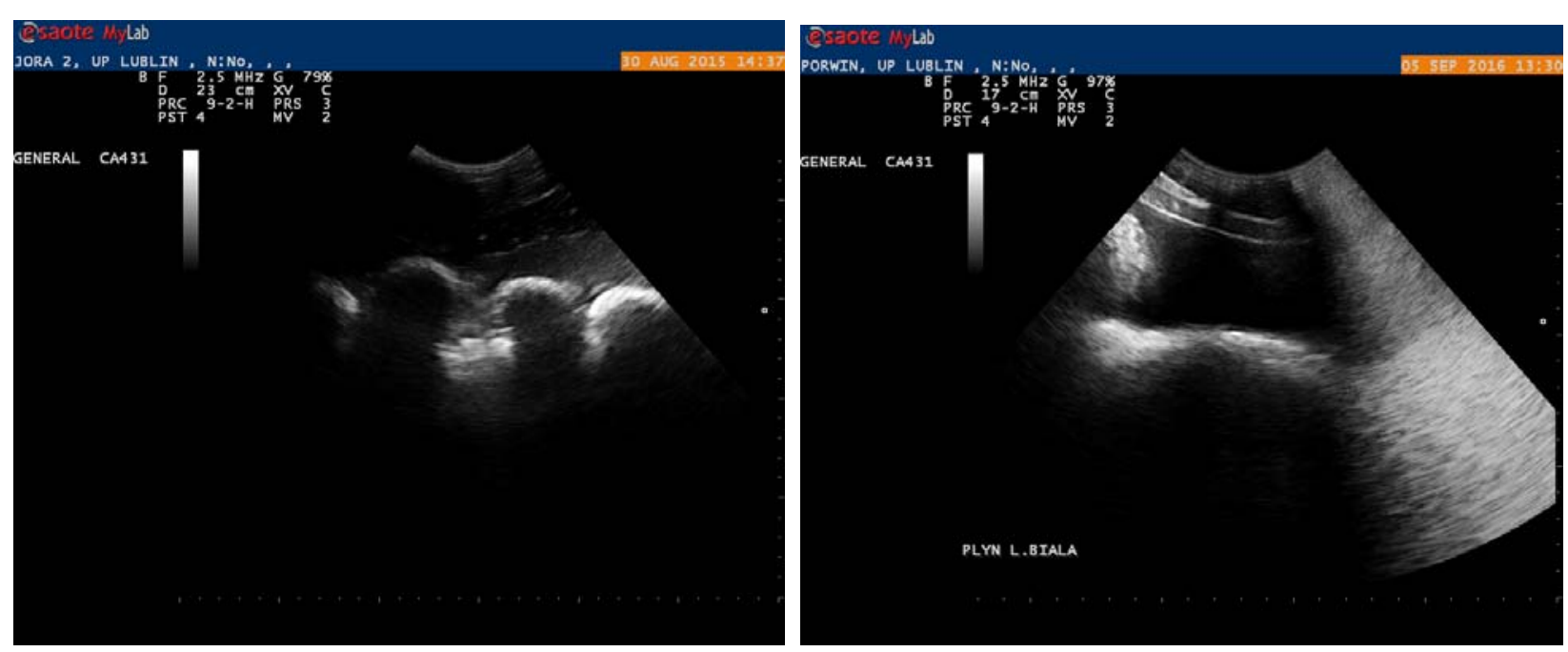


\section{Cel pracy}

Celem pracy było wykazanie skuteczności badania klinicznego oraz badania dodatkowego -badania ultrasonograficznego jamy brzusznej u konia.

\section{Materiały i metody}

Badanie przeprowadzono na 16 koniach $\mathrm{z}$ objawami kolki. Konie pochodziły $\mathrm{z}$ województwa lubelskiego. Zwierzęta były różnych raz, między 5-17 rokiem życia. 2 ogiery, 8 klaczy i 6 wałachów. Konie z grupy badawczej zostały poddane standardowemu badaniu klinicznemu, składającego się z mierzenia CTO oraz czasu wypełnienia kapilar, osłuchiwaniu jamy brzusznej, sondowaniu żołąkka oraz badaniu per rectum. $\mathrm{Na}$ tej postawie stawiano diagnozę. Następnie jako badanie dodatkowe wykonano badanie ultrasonograficzne jamy brzusznej według protokołu FLASH. Do badania wykorzystuje się sondę typu konwers o częstotliwości 2,5-3,5Mhz. Właściciele zwierząt, ze względów materialnych lub związanych z wiekiem konia nie wyrazili zgody na zabieg operacyjny. Badane konie zostały poddane eutanazji a następnie badaniu sekcyjnemu.

\section{Wyniki}

W 87,5\% przypadków padanie sekcyjne pokrywało się $\mathrm{z}$ rozpoznaniem $\mathrm{W}$ badaniu klinicznym. U $50 \%$ przypadków trafne rozpoznanie udało się postawić również przy pomocy badania ultrasonograficznego. U $30 \%$ pacjentów doszło do przemieszczenia okrężnicy dużej, co w 100\% udało się zobrazować i rozpoznać przy pomocy badania USG.

\section{Wnioski}

Badanie ultrasonograficzne jako badanie samodzielnie nie jest wystarczające $\mathrm{w}$ rozpoznawaniu przemieszczenia jelit u koni

Jest ono bardzo dobrym narzędziem do rozpoznawania ostrego brzucha. Tylko w około $50 \%$ przypadków można na podstawie badania ultrasonograficznego postawić ostateczne rozpoznanie.

Metodą USG nie możemy pewnych schorzeń wykluczyć, ale z całą pewnością możemy je potwierdzić.

\section{Literatura}

Beccatil, F. et al. (2012). Is there a statistical correlation between ultrasonographic findings and definitive diagnosis in horses with acute abdominal pain. Equine Vet J. Jan. 44(1), 120.

Busoni, V. et al. (2011). Evaluation of a protocol for fast localised abdominal sonography of horses (FLASH) admitted for colic. The Veterinary Journal Apr. 188, 77-82.

Ness SallyAnne, L. et al. (2012). Ultrasonographic visualization of colonic mesenteric vasculature as an indicator of large colon right distal displacement or 180 volvulus ( or both) in horses. Can Vet J. Apr. 53(4), 37882.

Reef Virginia, B. et al. (2004). Sonographic Evaluation of the Adult Abdomen. Clin Tech Equine Pract. 3, 294 307.

Стаття надійшла до редакиії 15.09.2016 